\title{
Distribution, management and diversity of yam local varieties in Brazil: a study on Dioscorea alata $L$.
}

\author{
Siqueira, MVBM. ${ }^{\text {a* }}$, Nascimento, $W F^{\mathrm{b}}$, Silva, LRG. ${ }^{b}$, Ferreira, $A B .^{\text {c }}$, \\ Silva, EF. ${ }^{\mathrm{d}}$, Ming, $L C$. $^{\mathrm{c}}$ and Veasey, $E A .^{\mathrm{b}}$ \\ ${ }^{a}$ Central de Laboratórios de Pesquisa, Ciência e Tecnologia Ambiental. Universidade Sagrado Coração (USC), \\ Rua Irmã Arminda, 10-50, Jardim Brasil, CEP 17011-160, Bauru, SP, Brazil. \\ 'Departamento de Genética, Escola Superior de Agricultura "Luiz de Queiroz" - ESALQ, Universidade de São Paulo - \\ USP, Av. Pádua Dias, 11, CP 83, CEP 13400-970, Piracicaba, SP, Brazil \\ ${ }^{c}$ Faculdade de Ciências Agronômicas, Universidade Estadual Paulista - UNESP, Fazenda Experimental Lageado, s/n, \\ Lageado, CEP 18603-970, Botucatu, SP, Brazil \\ ${ }^{\mathrm{d}}$ Departamento de Biologia, Universidade Federal Rural de Pernambuco - UFRPE, Rua Dom Manoel de Medeiros, s/n, \\ Dois Irmãos, CEP 52171-900, Recife, PE, Brazil \\ *e-mail: mvbsiqueira@gmail.com
}

Received: August 21, 2012 - Accepted: December 18, 2012 - Distributed: February 28, 2014

(With 1 figure)

\begin{abstract}
Widely spread in the tropics, yams were introduced into Brazil during the colonial period and are currently grown throughout the country. Despite its importance as a pharmacological and food source, there is a lack of studies describing how and where this tuber is grown in Brazil. The aim of this study was to provide an overview of the cultivation and distribution of Dioscorea alata in different Brazilian regions. A total of 63 farmers were visited in different municipalities and communities in four regions in the country: South, Southeast, Northeast and Midwest. Semi-structured interviews were conducted to collect socio-economic, use, management and diversity data for this crop. The majority of interviewers were men, married, with children, using retirement benefits and agriculture as income and family labour as the main support in the yam cultivation. A wide distribution of this species was found, with the occurrence of $D$. alata in the four sampled regions. A variety of vernacular names for this species was collected, differing according to the region where it is cultivated. Most farmers cultivate yams in fields, however an increased usage of home gardens for the cultivation of this tuber was found. Also, most farmers cultivate yams in association with other crops in areas of different sizes and slash and burn practices, although mostly disappearing, are still being used by many farmers. The results of this study provide more concrete data on the distribution and diversity of this important crop.
\end{abstract}

Keywords: agroecological diversity, Dioscorea, ethnobotany, in situ conservation, tubers.

\section{Distribuição, manejo e diversidade de variedades locais de inhame no Brasil: um estudo em Dioscorea alata $\mathrm{L}$.}

\begin{abstract}
Resumo
Amplamente difundido nos trópicos, o inhame entrou no Brasil na época da colonização e atualmente é cultivado em todo o país. Apesar de sua importância como cultura alimentícia e farmacológica, são raros os estudos que identifiquem como e onde esse tubérculo está sendo cultivado no Brasil. Este estudo teve como objetivo apresentar um panorama do cultivo e distribuição da espécie Dioscorea alata L. em diversas regiões do Brasil. Para tanto, foram visitados 63 agricultores em diferentes municípios, distribuídos entre o Sul, Sudeste, Nordeste e Centro-Oeste do país. Foram realizadas entrevistas semi-estruturadas, nas quais foram levantados dados socioeconômicos, bem como sobre o uso, manejo e diversidade dessa espécie. A maioria dos entrevistados eram homens casados, com filhos, que possuíam aposentadoria e a agricultura como principais fontes de renda. Constatou-se que a mão-de-obra familiar está bastante envolvida com o cultivo de inhame. Uma ampla distribuição da espécie foi observada, com a ocorrência de $D$. alata nas quatro regiões amostradas. Grande diversidade de nomes populares foi observada para a espécie neste estudo, com diferenças na nomenclatura popular em função das diferentes regiões onde a mesma é cultivada. A maioria dos agricultores cultiva inhame em roças, no entanto a importância dos quintais foi observada em vários municípios. Verificou-se também que a maioria dos entrevistados cultiva o inhame em consorciação com outras culturas e que a prática do pousio ainda é utilizada por muitos dos agricultores. Os resultados deste estudo permitiram gerar dados mais concretos sobre a distribuição e diversidade desta importante cultura.
\end{abstract}

Palavras-chave: diversidade agroecológica, Dioscorea, etnobotânica, conservação in situ, tubérculos. 


\section{Introduction}

Yam is a polyploid species of vegetative propagation that belongs to the Monocot class, Dioscoreaceae family, and Dioscorea genus (APG II, 2003). Dioscorea is the largest genus of the family, comprising approximately 600 species (Pedralli, 2002), of which 10 species (D. cayenensis Lam., D. rotundata Poir., D. alata L., D. bulbifera L., D. esculenta (Lour.) Burkill, D. trifida L., D. opposita Thunb., D. nummularia Lam., D. transversa $\mathrm{R}$. Br. and D. pentaphylla L.) are edible and represent the basic food source for more than 100 million people worldwide, especially in the humid and sub-humid tropics (FAO, 2009; Lebot, 2009). The first three species mentioned above are of great importance in the world, especially in Africa, where, along with cassava (Manihot esculenta Crantz), they represent the primary source of carbohydrates among different communities and ethnic groups (Odebunmi et al., 2007).

Dioscorea alata, one of the main commercial species in several states of Brazil, presents edible tubers of high nutritional quality. Some of its varieties derive from the "Florida" variety, originally from Puerto Rico and introduced in Brazil in the 1950's by the Agronomic Institute (IAC), in Campinas, São Paulo state. This variety, due to its uniform tubers and easy management, reached the commercial requirements throughout the years. However, its culinary qualities are not as appreciated as the "Mimoso" variety, which was extensively grown in the past but difficult to find nowadays in the market, mainly due to its susceptibility to anthracnose (Colletotrichum gloeosporioides Penz.) (Monteiro and Peressin, 2002).

Although yams can be cultivated on a large scale, it is within the small farmers' communities that they achieve their real importance, being a subsistence food source in several states. Local communities have maintained high genetic diversity of roots and tubers due to its economic and cultural value (Brush, 2005; Amorozo, 2008). However, factors such as the reduction of many farmer communities, the abandonment of the practice of family farming, the rapid growth and increase of monoculture and grazing areas, the replacement of local varieties by more productive commercial varieties, have induced genetic erosion of many crops, including the yam species (Dansi et al., 1997). Therefore, the need to rescue and preserve traditional knowledge to guide programs of germplasm conservation has become urgent in the last decades in conservation and breeding projects (Jarvis et al., 2000).

Although the cultivation of yam species in Brazil is possible in several regions (Carmo, 2002), there is a notorious lack of information regarding the cultivated area, productivity and size of properties dedicated to exploration of this crop (Zárate et al., 2002). These factors, coupled with the wide distribution of D. alata in Brazil, justify the inclusion of this species in the group of crops that deserves better attention as they are referred to as neglected or underutilised species (Siqueira and Veasey, 2009; Siqueira, 2011).
This study aimed to obtain an overview of the yam (D. alata) cultivation, diversity and distribution in various regions in Brazil, as well as the reality of the agriculturists that grow this crop within the rural systems where they are inserted.

\section{Material and Methods}

\subsection{Location of the study area}

Sixty-three farmers were visited in 28 municipalities, in a total of 46 communities distributed in the South, Southeast, Midwest, and Northeast regions in Brazil (Figure 1, Table 1). In the South, farmers were visited in the State of Santa Catarina (SC), in the municipalities of Joinville, Itajaí and São Francisco do Sul. The climate in this area is classified according to Köeppen (1948) as CFA mesothermal humid subtropical with hot summers. The average annual temperature is $16-20^{\circ} \mathrm{C}$ and the average annual rainfall ranges from 1,700 to $2,500 \mathrm{~mm}$. The relative average humidity is 82 to $86 \%$.

The area studied in the Southeast region presents humid climate. The average temperature in the coldest month (July) is $18.1^{\circ} \mathrm{C}$ and in the warmest month (January) is $25.7^{\circ} \mathrm{C}$. Rainfall ranges from 1,500 to $4,000 \mathrm{~mm}$ and the vegetation is composed by the Atlantic Tropical Rain Forest (Morellato et al., 2000). In this region three municipalities were visited: Ubatuba, Mogi Guaçu and Moji Mirim (Figure 1; Table 1).

In the Northeast, fifteen municipalities were visited in four states: Paraíba, Maranhão, Pernambuco and Piauí (Figure 1; Table 1). Most of the municipalities visited in this region are located in the coastal and forest zone, where the climate is humid and semi-humid. The municipalities located in the coastline have higher incidence of rain and are situated in the Atlantic Forest biome. Some municipalities visited are located in the Caatinga biome, which has a low incidence of rain (IBGE, 2012).

In the Midwest region we focused on the territory of Baixada Cuiabana, Mato Grosso (MT). This region consists of 13 municipalities around the state capital, Cuiabá, covering an area of $85,369.70 \mathrm{~km}^{2}$. In this region, both the Cerrado and the Pantanal are present and the semi-humid climate prevails. The temperatures are high all over the year, with an average of $25^{\circ} \mathrm{C}$ and the average annual rainfall remains between 1,300 and $1,600 \mathrm{~mm}$ of rain (IBGE, 2012).

\subsection{Data collection and data analysis}

The person responsible for the households that cultivated D. alata was interviewed, after agreeing to participate in this study. This research was approved by the Ethics Committee in Research with Human Beings of Luiz de Queiroz College of Agriculture, University of São Paulo on 18 December 2007. The semi-structured interviews were designed to gather data on the socio-economic status of the respondents, as well as their planting areas and crops diversity. For the socio-economic characterisation, the farmers' name, community, age, sex, marital status, number of children, place of birth, residence time at the site, land 


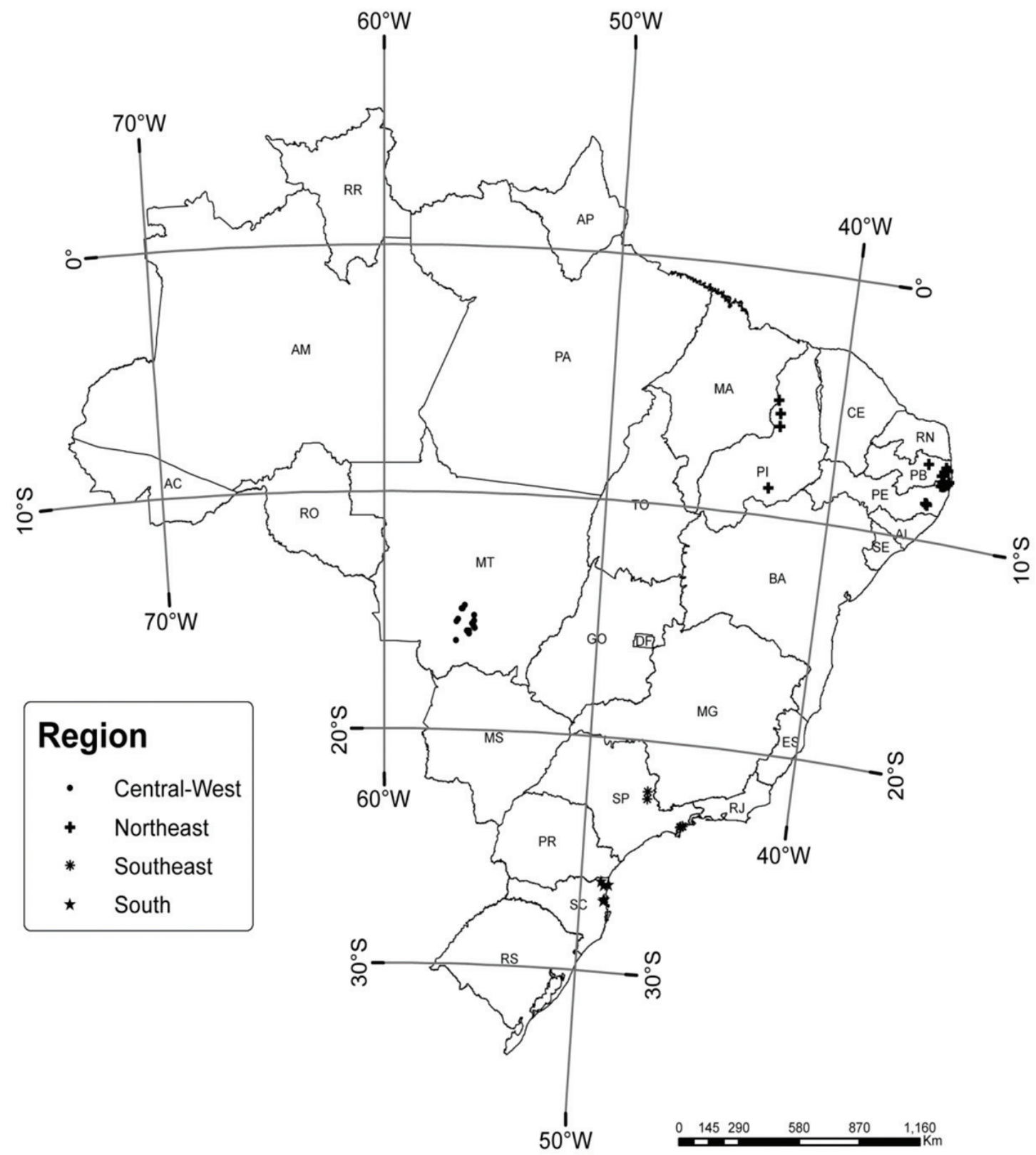

Figure 1. Collection sites of Dioscorea alata in four regions of Brazil: South, Southeast, Northeast and Midwest.

tenure, source of income, total area of the property and labour involved in the work done in the property were obtained to create a more realistic profile of each region.

To characterise the management, diversity and growing areas of the species, the following information was collected: total size of the property; place of yam cultivation (home gardens and/or fields) and its size; planting system (consortium and/or individual planting); the popular name of local varieties and their origin; the origin of the nomenclature used for some local varieties; the planting season; the intended use (consumption); and the report of flowering and fructification for each mentioned variety.
Qualitative data was analysed by using descriptive statistics and presented as means, percentages, frequency distributions, and cross tables.

\section{Results and Discussion}

\subsection{Socio-economic characterization of farmers}

Most interviewed farmers were male (87\%), and mostly married $(81 \%)$, with a low number of single (8\%), cohabitating ( $8 \%$ ) and widowers (3\%) (Table 2). The age ranged from 21 to 83 years, with the age group of $61-70$ years having the highest percentage of respondents (29.7\%), 
Table 1. Region, state, municipality, communities and number of interviewed farmers.

\begin{tabular}{|c|c|c|c|c|}
\hline Region & State & Municipality & Community & Interviews $\left(\mathrm{n}^{0}\right)$ \\
\hline Northeast & Paraíba & Sapé & Melancia & 1 \\
\hline “ & " & Alhandra & $\begin{array}{l}\text { Sítio Acaz de Baixo; Jussara; Faz. } \\
\text { Vale Verde; Sítio Canaã }\end{array}$ & 4 \\
\hline “ & “ & Rio Tinto & Boa Vista & 2 \\
\hline “ & “ & Mamanguape & Monte Alegre & 1 \\
\hline “ & “ & Sobrado & Caruncú; Sítio Anta dos Sonhos & 2 \\
\hline “ & “ & Marcação & Lagoa Grande & 1 \\
\hline “ & “ & Caaporã & Sítio Capim de Cheiro & 3 \\
\hline “ & Maranhão & Pedreiras & Canto do Buriti & 1 \\
\hline “ & Pernambuco & Condado & Sítio Patrimônio & 1 \\
\hline “ & “ & Aliança & Sítio Laranjeira; Boa Vista & 2 \\
\hline “ & “ & Bonito & Fazenda Ferro; Sítio Mucurí & 2 \\
\hline “ & “ & São Joaquim dos Montes & Sítio Tamanduá & 1 \\
\hline “ & Piauí & Regeneração & Chapada Grugel & 1 \\
\hline “ & “ & Água Branca & Cedro & 1 \\
\hline “ & “ & Vila Irmã Dulce & Vila Irmã Dulce & 1 \\
\hline Total & & & & 24 \\
\hline South & Santa Catarina & Itajaí & Laranjeiras; São Roque & 2 \\
\hline “ & “ & Joinville & Pirabeiraba; Comunidade Quiriri & 3 \\
\hline “ & “ & São Francisco do Sul & Acaraí & 1 \\
\hline Total & & & & 6 \\
\hline Southeast & São Paulo & Ubatuba & $\begin{array}{l}\text { Sertão do Ingá; Rio Escuro; Sertão } \\
\text { do Quina }\end{array}$ & 4 \\
\hline “ & “ & Mogi Guaçu & Itaqui & 1 \\
\hline “ & “ & Mogi Mirim & - & 1 \\
\hline Total & & & & 6 \\
\hline Midwest & Mato Grosso & Cuiabá & $\begin{array}{l}\text { Rio dos Couros; P.A } 21 \text { de abril; } \\
\text { São Genônimo; P.A Bela Vista; } \\
\text { Raizama }\end{array}$ & 12 \\
\hline “ & “ & $\begin{array}{l}\text { Santo Antonio do } \\
\text { Leverger }\end{array}$ & $\begin{array}{l}\text { Praia do Poço; Valo Verde; } \\
\text { Barreirinho; Alto do Leverger; } \\
\text { Engenho Velho }\end{array}$ & 6 \\
\hline “ & “ & Poconé & Córrego Fundo & 1 \\
\hline “ & “ & $\begin{array}{l}\text { Nossa Senhora do } \\
\text { Livramento }\end{array}$ & P.A Aterrado & 2 \\
\hline “ & “ & Nobres & Sela Dourada & 1 \\
\hline “ & “ & Rosário Oeste & Timbozal; Barranco Alto & 2 \\
\hline “ & “ & Jangada & $\begin{array}{l}\text { Sto. Antonio do Barreiro; P.A. } \\
\text { Canoa Furada }\end{array}$ & 3 \\
\hline Total & & & & 27 \\
\hline
\end{tabular}

followed by the ages of 41-50 years $(20.3 \%)$ and 51-60 years (18.7\%). Among the 63 farmers, $62 \%$ indicated that they migrated from other regions and $38 \%$ were born and settled where they live today. Of the 22 couples reported in the Northeast, only two respondents were under 30 years of age. In the South, Southeast and Midwest all married respondents were over 30 years of age. A lack of young farmer couples in the sampled regions was observed and this is a factor to take into account when discussing the aging of rural population.

Currently, rural areas are becoming less attractive to younger generations (Anjos and Caldas, 2005), and consequently the average age of the farmers is increasing. The most referred reason for this phenomenon, in this study, was the reduced financial support from the government. This, together with the physical effort in agriculture work, low income, lack of infrastructure for child education, e.g. access roads, schools, and health care, reflects in the decrease of the yam growing areas in various types of agricultural systems, especially in traditional and local communities.

Farming areas are decreasing with a profound impact on the familiar rural structure and one of the reasons is the exodus of young people (Godoy et al., 2010); households 
Table 2. Profile of respondents according to sex, age, origin, marital status and number of children for each region and total number and total percentage.

\begin{tabular}{|c|c|c|c|c|c|c|c|}
\hline \multicolumn{2}{|c|}{$\begin{array}{l}\text { Characteristics of } \\
\text { respondents }\end{array}$} & \multirow{2}{*}{$\begin{array}{c}\text { Northeast } \\
24\end{array}$} & \multirow{2}{*}{$\begin{array}{c}\text { South } \\
5\end{array}$} & \multirow{2}{*}{$\begin{array}{c}\text { Southeast } \\
5\end{array}$} & \multirow{2}{*}{$\begin{array}{c}\text { Midwest } \\
21\end{array}$} & \multirow{2}{*}{$\begin{array}{c}\text { Total } \\
55\end{array}$} & \multirow{2}{*}{$\begin{array}{c}\begin{array}{c}\text { Total } \\
\text { (\%) }\end{array} \\
87.0\end{array}$} \\
\hline Sex & Male & & & & & & \\
\hline \multirow{8}{*}{ Age (years) } & Female & 0 & 1 & 1 & 6 & 8 & 13.0 \\
\hline & 21 to 30 & 3 & 0 & 0 & 2 & 5 & 7.8 \\
\hline & 31 to 40 & 5 & 1 & 0 & 0 & 6 & 9.4 \\
\hline & 41 to 50 & 4 & 1 & 2 & 6 & 13 & 20.3 \\
\hline & 51 to 60 & 1 & 1 & 2 & 8 & 12 & 18.7 \\
\hline & 61 to 70 & 7 & 1 & 1 & 10 & 19 & 29.7 \\
\hline & 71 to 80 & 4 & 1 & 1 & 1 & 7 & 10.9 \\
\hline & More than 80 & 0 & 1 & 0 & 1 & 2 & 3.2 \\
\hline \multirow[t]{2}{*}{ Origin } & Local & 7 & 2 & 1 & 14 & 24 & 38.0 \\
\hline & Out & 17 & 4 & 5 & 13 & 39 & 62.0 \\
\hline \multirow{4}{*}{$\begin{array}{c}\text { Marital } \\
\text { status }\end{array}$} & Single & 2 & 0 & 1 & 2 & 5 & 8.0 \\
\hline & Married & 22 & 6 & 3 & 20 & 53 & 81.0 \\
\hline & Widower & 0 & 0 & 2 & 0 & 2 & 3.0 \\
\hline & Cohabitating & 0 & 0 & 0 & 5 & 5 & 8.0 \\
\hline \multirow{5}{*}{$\begin{array}{l}\text { Number of } \\
\text { children }\end{array}$} & None & 2 & 0 & 1 & 2 & 5 & 8.0 \\
\hline & $1-2$ & 2 & 3 & 0 & 17 & 22 & 35.0 \\
\hline & $3-5$ & 10 & 1 & 5 & 9 & 25 & 40.0 \\
\hline & $6-10$ & 5 & 2 & 0 & 0 & 7 & 11.0 \\
\hline & $>10$ & 4 & 0 & 0 & 0 & 4 & 6.0 \\
\hline
\end{tabular}

in the village consist predominantly of older couples living alone, elderly couples with grandchildren, and elderly couples with a single daughter or son (Woortmann, 1990; Wanderley, 2000). The young children usually live with their grandparents in the community until they finish elementary school. Most often, young people migrate to urban areas in order to get a job and during the weekend return to work in the farm belonging to their family.

Regarding the number of children per couple, $40 \%$ of respondents have three to five children, $35 \%$ one to two, $11 \%$ from six to ten, $6 \%$ more than ten children, and $8 \%$ do not have any children (Table 2). All respondents showed great interest in having their children remain at school to pursue their studies, even if it reduces the agricultural activities in the households. However, the vast majority of children helped with the agricultural labour, after the school period or during holidays. The continuation of family farming occurs endogenously, in the family, with the successor traditionally being a family member (Carneiro, 2001). In this study it was observed that when the parents died, the fields were abandoned and used very rarely or sold by their children. The replacement of family labour in the fields are nowadays difficult or in some cases impossible. This situation was observed in all communities analysed.

Considering the source of respondents income, $50 \%$ reported living from retirement and agriculture, $36 \%$ derive their income from agriculture, $11 \%$ had other forms of income as temporary work such as carpentry, construction, among others, and $3 \%$ of farmers stated that their only source of income was from retirement. Despite this classification, all interviewed farmers spent some of their time in agriculture, particularly in the yam planting. However, more than $50 \%$ reported having temporary jobs unrelated to agriculture at some point of their lives, such as civil construction and housekeeping. These activities contribute to the increase in family income. This is a good example of the phenomenon of pluriactivity that has been occurring in rural areas. Agriculture is practiced simultaneously with the exercise of other different activities. Some authors have argued that certain households are pluriactive just to maintain their household income and/ or to pay for necessities (Bowler, 1996). This is a trend noticed in several Brazilian municipalities, including the areas where the study was conducted (Schneider, 2003; Otani et al., 2011).

The retirement income was very important for most households, while agriculture is a supplement to the low income that most farmers claimed to receive. There is an increasing number of rural retirements by age, which shows the aging of the rural population, and also a better redistribution of the income in these elderly people. In the past, the primary source of income was agriculture, but nowadays this is complemented by a pension (Augusto and Ribeiro, 2005).

The interviews showed that $72 \%$ of farmers employ only family labour for agricultural work. Approximately 17\% of respondents rely on family members and acquaintances and $11 \%$ apply only to the aid of people hired or neighbours 
who participate in community action for compliance with agricultural activities.

One of the major driving forces in yam cultivation in Brazil, particularly in the state of Espírito Santo, is the use of family labour and subsistence gains (Juliatti et al., 2002). This family relationship was observed in all regions of this research, even when the cultivation of yams was for market. Some exceptions were observed when the landowner contracted for temporary workers. Other studies outside Brazil consider family labour in the field a vital item in maintaining the knowledge and generation of new yam varieties and other subsistence crops (Chair et al., 2010; Gaillard and Manner, 2010). The yam crop is a major employer in various regions of Brazil, mainly in the Northeast (Santos and Macêdo, 2002). Some authors (Gliessman, 2005; Barros and Silva, 2010) have suggested new ways for an environmentally sustainable, socially just and economically viable rural development, through family farming in polyculture systems.

\subsection{Characterization of the crop areas for Dioscorea alata}

The majority of the interviewed farmers maintain their yam crops in the field (73\%), while 14\% use both the field and home gardens. The remaining $13 \%$ grow yams only in their home gardens. According to the interviewed farmers, yams were planted basically in the field, but the decrease of labour force replacement, the ageing of farmers and more restrictive environmental laws forced them to use home gardens more frequently. Home gardens are generally small, located near the household and maintained by family labour (Winklerprins, 2002), and are characterized by presenting high species diversity, with multiple purposes, which coexists with domesticated or wild animals, including horticultural crops for subsistence purposes (Miller and Nair, 2006; Galluzzi et al., 2010). In most cases, they represent an important alternative area when the farmer is unable to keep their crops in the field.

It was difficult to obtain consistent information regarding the size of planting area for D. alata, particularly in the region of Ubatuba, SP, Southeast, where there are ongoing conflicts between supervisory authorities of protected areas and the farmers (Otani et al., 2011). Approximately $12 \%$ of farmers reported not knowing the extent of their cultivation areas. However, in the four regions sampled, the size of the growing areas of the species was variable, from 10 square meters to 60 ha approximately; the specific size of the area is mostly related to the purpose of cultivation for self consumption or the market.

The average area for the yam cultivation in the South and Southeast was 40.9 ha. However, this value does not reflect the reality since, by observation, most of these fields were no more than 5 ha. One farmer in Ubatuba, SP, reported planting on a large scale, 59 ha. In the municipality of Mogi Guaçu, SP, a large-scale farmer was interviewed; this farmer cultivates the Florida variety in the majority of his property for commercial purposes, with approximately 142 ha. In the Northeast, the average area for planting yams was 4 ha, ranging from 0.02 ha (Pedreiras, MA and Mamanguapé, PB) to 30 ha (São Joaquim do Monte, PE).

In the sampled region in the Midwest, whose properties size varied from 2 ha (households in Cuiabá and Santo Antonio do Leverger municipalities) to 81 ha (in Jangada municipality), it was not possible to know exactly the size intended for the cultivation of the species, since farmers have cited this information by the number of "tumbas" (small mounds of gathered soil that cover each tuber), which ranged from a few units to about 220 "tumbas". It was observed that $41 \%$ of these farmers grow yams in an area with more than 10 "tumbas". This form of planting is very common in traditional agriculture, where the soil is gathered in small mounds. The size of each mound, average distances between them and the number of yam plants can vary, i.e., the higher the mound, the greater the distance between them (Okoli and Onwueme, 1986). The term "matumbo" is also found in literature and refers to the same cultivation method (Santos, 1996).

Therefore, in most of the regions sampled, there are farmers who grow yams not only for subsistence, but also for commercial purposes, in medium and large field areas. However, for most interviewed, the products obtained in the agricultural practices serve only to supplement the family diet, as the vast majority are represented by areas of reduced size and, therefore, are considered small producers.

Reports from farmers point out that once the "fallow", rest given to the farmland, interrupting the cultivation to make the soil more fertile, was a common practice, but currently the practice has lost supporters. It is known that fallow brings many advantages to the farmer, especially for the soil, making it free of any pathogens, and allows the soil to improve its capacity to retain water in dry areas and fertility restoration (Gliessman, 2005). With high population and environmental pressures there is less land available and fallow periods are shorter. The reduction of the fallow period, along with the biomass burning and excessive use of natural resources, lead to a reduction of organic matter and soil nutrients, and consequently, lower yields and increased genetic erosion. During the interviews some farmers preferred not to reveal the fallow practice, since in some cases it is linked to opening up new fields, which is considered an environmental crime if done without prior approval from the authorities; this situation occurred more frequently in the Southeast. The explanation to this fact is linked to the study areas. Some of the interviews in the Southeast region resided in the frontier to nature parks, and this situation involves several restrictions. Among those who declared using this practice, the fallow period varied from six months to three years, which is a very short period and indicative of a transition to a more intensive agriculture system. Intensive systems are associated, among others, with a reduction in fallow lengths and also a reduction in the diversity of landraces in general (Gaillard and Manner, 2010; Van Vliet et al., 2012). Gaillard and Manner (2010) reported that the loss of yam varieties in New Caledonia has accelerated and commercial varieties are supplanting traditional varieties. 
According to the authors, the modernization of agriculture is changing the yam crop practices in the region.

In conclusion, a significant portion of respondents in the Northeast, South and Southeast ( $41 \%$ of farmers), still maintain crop fallows, $42 \%$ abandoned the practice and $17 \%$ did not comment. In the Midwest this data was not obtained during the interviews.

\subsection{Characterization of the folk nomenclature for Dioscorea alata}

Farmers in the South, Southeast and Midwest regions denominate tubers of $D$. alata by the name of cará, while in the Northeast region this species is popularly known as inhame. Within these two terms, much variation was observed, with a total of 21 vernacular names cited to the local $D$. alata varieties. The highest percentage of citation was for the name inhame de São Tomé (26.8\%), followed by cará roxo $(12.7 \%)$, cará branco $(12.7 \%)$, and simply cará $(11.3 \%)$ (Table 3$)$.

In the Northeast region the species is known mostly as inhame São Tomé, although this species is also known locally as inhame branco, inhame roxo, inhame mandioca, inhame de Pernambuco, inhame babão and inhame roxo bolota. The diversity of names in this region is strongly related to the wide tuber morphological differences. In the South, in the municipalities of Itajaí, Joinville and São Francisco do Sul, in the State of Santa Catarina, the species is best known as cará roxo. Variations of the name as cará pão roxo and cará pão branco were also found. The rest of the interviewed farmers named the species simply as cará. The origin of the name cará pão, as reported by local farmers, dates back to World War II, due to the scarcity of wheat, when the tubers of D. alata were used for making bread (Veasey et al., 2010).

In the Southeast, specifically in Ubatuba, the terms varied from cará roxo, cará branco, and cará pé de cavalo, while farmers who cultivate it for commercial purposes, in the municipalities of Mogi Guaçu and Mogi Mirim, name them Florida (well known commercial variety) or simply cará (Table 3 ). On the southern coast of São Paulo, in the region of Vale do Ribeira, this species is also known as cará guaçu (ranging from cará guaçu roxo or cará guaçu branco), cará São João (due to their harvest during St. John's celebration festivity in June), cará aipim, cará bolo and cará coco (Bressan et al., 2005). The wealth of data found by these last authors took into account the region of Vale do Ribeira, where the practice of traditional agriculture is maintained. Nevertheless, from the data raised here, a regionalization within the state of São Paulo with different nomenclatures for the species was observed. Like other vegetative propagated crops, yams are cultivated and maintained by farmers for their agrobotanical, taxonomic or gastronomical characteristics, and because of that, several names are assigned to new local varieties when they are introduced in the homegardens (Chair et al., 2010). Some authors (Asemota et al., 1996; Dansi et al., 1999; Pedralli et al., 2002) observed a considerable variation in linguistic terms in the nomenclature of the local yam varieties, where each location has its own variable names for different cultivars.

In the Midwest region, in Mato Grosso, there was a great diversity of vernacular names assigned to the species registered as cará roxo, cará branco, cará, cará lavanca,

Table 3. Number of farmers by state for each variety quoted from Dioscorea alata and the total citations (\%) for each variety.

\begin{tabular}{|c|c|c|c|c|c|c|c|c|}
\hline Varieties & PE & PB & MA & PI & SP & SC & MT & Total (\%) \\
\hline Inhame São Tomé & 6 & 13 & - & - & - & - & - & 26.8 \\
\hline Inhame branco & - & - & - & 3 & - & - & - & 4.2 \\
\hline Inhame roxo & - & - & 1 & 1 & - & - & - & 2.8 \\
\hline Inhame roxo bolota & - & - & - & 1 & - & - & - & 1.4 \\
\hline Inhame babão & 1 & - & - & - & - & - & - & 1.4 \\
\hline Inhame mandioca & - & - & - & 1 & - & - & - & 1.4 \\
\hline Inhame de PE & - & - & 1 & - & - & - & - & 1.4 \\
\hline Cará roxo & - & - & - & - & 1 & - & 8 & 12.7 \\
\hline Cará branco & - & - & - & - & 3 & - & 6 & 12.7 \\
\hline Cará & - & - & - & - & 1 & 1 & 6 & 11.3 \\
\hline Cará lavanca & - & - & - & - & - & - & 3 & 4.2 \\
\hline Cará pão branco & - & - & - & - & - & 2 & - & 2.8 \\
\hline Cará pão roxo & - & - & - & - & - & 3 & - & 4.2 \\
\hline Cará arroba & - & - & - & - & - & - & 2 & 2.8 \\
\hline Cará pão & - & - & - & - & - & 1 & - & 1.4 \\
\hline Cará pele roxa & - & - & - & - & - & - & 1 & 1.4 \\
\hline Cará canga or cenoura & - & - & - & - & - & - & 1 & 1.4 \\
\hline Cará cipó & - & - & - & - & - & - & 1 & 1.4 \\
\hline Cará pé de cavalo & - & - & - & - & 1 & - & - & 1.4 \\
\hline Cará manchado & - & - & - & - & - & - & 1 & 1.4 \\
\hline Flórida & - & - & - & - & 1 & - & - & 1.4 \\
\hline
\end{tabular}


cará arroba, among others with minor citations (Table 3). A survey conducted by Ferreira et al. (2010) in Mato Grosso noted that the vernacular names are connected with the classification and identification made by farmers for each Dioscorea species and according to each region. The greater diversity of vernacular names observed in this study for the Northeast and Midwest regions may also reflect the higher sampling effort in these areas, where a higher number of municipalities were visited (Table 1) and, therefore, a greater amount of vernacular names were registered.

Regarding the number of $D$. alata local varieties grown by the farmers, $85 \%$ cultivate only one variety and $14 \%$ grow two to three local varieties, and rarely $(1 \%)$ more than three. In the Northeast, only farmers visited in the States of Piauí and Maranhão grow two to three local varieties. In Santa Catarina, of six farmers who cultivated the species, only two grow more than one local variety, and in Ubatuba, São Paulo, only one farmer presented two local varieties in their fields. In the Midwest, from a total of 27 farmers, only three maintained two local varieties in their fields, while the others had only one variety. This is a finding that differs, for example, from cassava, where farmers usually grow more than one local variety in their fields (Emperaire and Peroni, 2007).

\subsection{Origin of Dioscorea alata local varieties and their uses}

When asked about the origin of the yam local varieties, the majority of those interviewed was unaware of their origin. Some farmers received tubers from neighbours, or bought them in the market, or stated that the yam variety was already there when they started to work in the land. Another important reference on this issue was information received from their parents or close relatives who possessed these varieties.

All farmers use small sections or small tubers which they call "seed" for vegetative propagation of $D$. alata. The farmers reported flowering in $68.8 \%$ of the cases, but no reference was made to fructification. According to Abramo (1990), flowering periods in yam are rare events. Monteiro and Peressin (2002) pointed out that flowering of the species is rare in Brazil. Bressan et al. (2011) reported flowering in only $8.6 \%$ from a total of 35 D. alata accessions grown under experimental conditions in Piracicaba, São Paulo, and no seed was produced from the flowering plants. Lebot (2009) states that unfortunately, and in most cases, the varieties that have the best features, whether agronomic (compact tubers, for example) or palatability characteristics, are those that do not flower. According to the author, flowering of the species in India is between September and November, and in Melanesia, from April to June, both considered centres of diversity and origin of this species, respectively. In view of the literature reports and the high amount of farmers $(68.8 \%)$ reporting flowering in this study, we argue that the high percentage of farmers that observed flowering in D. alata was attributed to the long experience of farmers in the field. It should be pointed out that the question was not focussed on the current year of the interview but on the farmer observing flowering at any moment during his experience with the crop.

Interestingly, most visited farmers plant yam intercropped with other crops (59\%), which is more typical of small farmers who use the crop for subsistence. However, there were also a large number of farmers who plant yams separately (41\%) for commercial use or not. Although there are some technical restrictions on the cultivation of yams in the intercropping system, such as lower productivity, greater exposure to phytosanitary problems, among others, it is known that complementary crops favour the producer economically, reducing production costs of the main crop and allowing better use of available labour (Ijoyah, 2011). Some crops are more suitable for intercropping with yams such as beans, peanuts, soybeans and watermelon (Peixoto Neto et al., 2000). However, among all regions surveyed, crops such as corn, sunflower, sorghum and cassava were those found in this study, the latter being the most frequent in the four regions analysed. According to Peixoto Neto et al. (2000), several aspects are important when selecting the consortium. However, an important factor is that many crops compete in a more compromising way than others, not only by the requirement of nutrients, as well as the excessive water consumption, especially if the crop shows a longer growing season, such as yams.

Regarding consumption, D. alata, as well as the species complex $D$. cayenensis- $D$. rotundata, is commonly used as a food source, as it is rich in carbohydrates and proteins (Pedralli et al., 2002; Odebunmi et al., 2007). In the Northeast, yams are cooked with butter. In Santa Catarina, this species is consumed as flour, which is used in the manufacture of breads and biscuits. The older respondents also maintain the habit of consuming it as a supplement for breakfast. In the other areas of this study the use of yams in preparation of soup, bread and in substitution to boiled potato were also reported. Some authors have rescued traditional recipes using yams in their preparation, which are dishes originated in rural communities from several regions of Brazil (Peixoto Neto et al., 2000; Brasil, 2010). The use of yam flour for bread production could be profitable for small farmers, considering that its use in the manufacture of snack foods has shown characteristics desired by consumers (Alves and Grossmann, 2002). The generation of a new income from cooperatives, together with small-scale farmers, using yam and other underutilized crops might be quite promising.

It is noteworthy that the characterization of farmers conducted in this paper represents only a small part of Brazil's rural population engaged in the cultivation of yams. However, even in the small universe studied, this work showed that yam cultivation activity is of great importance to farmers in Brazil. This study also showed that there is a clear regionalization in the assignment of popular names for $D$. alata local varieties, according to their morphology, uses or origin. The role of farmers in maintaining the local agro-biodiversity, whether in home 
gardens or fields, is important for the maintenance of the genetic diversity of yams and other crops over generations (Chair et al., 2010; Siqueira et al., 2010; Bressan et al., 2011; Veasey et al., 2012). However, for these varieties to be maintained at an on farm conservation basis, agroecological conservation policy goals must be considered, as well as more studies emphasising the importance of yams in rural areas.

Acknowledgements - The authors would like to thank the researchers Nivaldo Peroni, Antônio Henrique dos Santos, Danielle Silva, Caroline Blumer, Tatiana Miranda, Alejandro Coca, Rita Piedade, Tom Wray and all the farmers for their contributions in the field collecting, interviews and suggestions which helped to improve the manuscript. We are also grateful to the "Fundação de Amparo à Pesquisa do Estado de São Paulo" and the "Conselho Nacional de Pesquisa e Desenvolvimento Científico e Tecnológico" for financial support for this study.

\section{References}

ABRAMO, MA., 1990. Taioba, cará e inhame: o grande potencial inexplorado. São Paulo: Editora Ícone. 80 p.

ALVES, RM. and GROSSMANN, MVE., 2002. Parâmetros de extrusão para produção de "snacks" de farinha de cará (Dioscorea alata). Ciência e Tecnologia de Alimentos, vol. 26, no. 2, p. 32-38.

ANJOS, FS. and CALDAS, NV., 2005. O futuro ameaçado: o mundo rural face aos desafios da masculinização, do envelhecimento e da desagrarização. Ensaios FEE, vol. 26, no. 1, p. 661-694.

AMOROZO, MCM., 2008. Maintenance and management of agrobiodiversity in small-scale Agriculture. Functional Ecosystems and Communities, vol. 2, no. 1, p. 11-20.

Angiosperm Phylogeny Group - APG II, 2003. An update of the Angiosperm Phylogeny Group classification for orders and families of flowering plants: APG II. Botanical Journal of the Linnean Society, vol. 161, no. 2, p. 399-436.

ASEMOTA, HN., RAMSER, J., LOPÉZ-PERALTA, C., WEISING, K. and KAHL, G., 1996. Genetic variation and cultivar identification of Jamaican yam germplasm by random amplified polymorphic DNA analysis. Euphytica, vol. 92, no. 2, p. 341-351.

AUGUSTO, HA. and RIBEIRO, EM., 2005. O envelhecimento e as aposentadorias no ambiente rural: um enfoque bibliográfico. Organizações rurais e agroindustriais, vol. 7, no. 2, p. 199-208.

BARROS, JDS. and SILVA, MFP., 2010. Práticas agrícolas sustentáveis como alternativas ao modelo hegemônico de produção agrícola. Sociedade e Desenvolvimento Rural, vol. 4, no. 2, p. 89-103.

BOWLER, IR., 1996. Agricultural change in developed countries. Cambridge: Cambridge University Press. 96 p.

BRASIL. Ministério da Agricultura, Pecuária e Abastecimento, 2010. Hortaliças não-convencionais: (tradicionais). Brasília: MAPA/ACS. 52 p.

BRESSAN, EA., VEASEY, EA., PERONI, N., FELIPIM, AP. and SANTOS, KMP., 2005. Collecting yam (Dioscorea spp.) and sweet potato (Ipomoea batatas) germplasm in traditional agriculture small-holdings in the Vale do Ribeira, São Paulo, Brazil. Plant Genetic Resources Newsletter, vol. 144, no. 144, p. 8-13.
BRESSAN, EA., BRINER NETO, T., ZUCCHI, MI., RABELLO, RJ. and VEASEY, E.A., 2011. Morphological variation and isozyme diversity in Dioscorea alata L. landraces from Vale do Ribeira, Brazil. Scientia Agrícola, vol. 68, no. 4, p. 494-502. http://dx.doi. org/10.1590/S0103-90162011000400016

BRUSH, SB., 2005. Protecting traditional agricultural knowledge. Journal of Law and Policy, vol. 17, p. 59-109.

CARMO, CAS., 2002. Inhame e taro: sistemas de produção familiar. Vitória: Incaper. 289 p.

CARNEIRO, MJ., 2001. Herança e gênero entre agricultores familiares. Revista Estudos Feministas, vol. 9, no. 1, p. 22-55. http://dx.doi.org/10.1590/S0104-026X2001000100003

CHAIR, H., CORNET, D., DEU, M., BACO, MN., AGBANGLA, A., DUVAL, MF. and NOYER, JL., 2010. Impact of farmer selection on yam genetic diversity. Conservation Genetics, vol. 11, no. 6, p. 2255-2265. http://dx.doi.org/10.1007/s10592-010-0110-z

DANSI, A., ZOUNDJIHEKPON, J., MIGNOUNA, HD. and QUIN, M., 1997. Collecte d'ignames cultivées du Complexe Dioscorea cayenensis - rotundata au Benin. Plant Genetic Resources Newsletter, vol. 112, p. 81-85.

DANSI, A., MIGNOUNA, HD., ZOUNDJIHEKPON, J., SANGARE, A., ASIEDU, R. and QUIN, FM., 1999. Morphological diversity, cultivar groups and possible descent in the cultivated yams (Dioscorea cayenensis/D. rotundata) complex in Benin Republic. Genetic Resources and Crop Evolution, vol. 46, no. 4, p. 371-388. http://dx.doi.org/10.1023/A:1008698123887

EMPERAIRE, L. and PERONI, N., 2007. Traditional management of agrobiodiversity in Brazil: a case study of manioc. Human Ecology, vol. 35, no. 6, p. 761-768. http://dx.doi.org/10.1007/ s10745-007-9121-x

Food and Agriculture Organization of the United States - FAO, 2009. FAOSTAT Agriculture data. FAO. Available from: $<\mathrm{http}: / /$ apps.fao.org/collections>. Access in: 16 mar. 2009.

FERREIRA, AB., MING, LC., CHECHETTO, F. and PINTO, RA., 2010. Dioscoreáceas cultivadas por agricultores da Baixada Cuiabana em Mato Grosso - Brasil. Revista Raizes e Amidos Tropicais, vol. 6, no. 1, p. 201-208.

GAILLARD, C. and MANNER, HI., 2010. Yam cultivation on the East Coast of New Caledonia: adaptation of agriculture to social and economic changes. Australian Geographer, vol. 41, no. 4, p. 485-505. http://dx.doi.org/10.1080/00049182.2010.519697

GALLUZZI, G., EYZAGUIRRE, P. and NEGRI, V., 2010. Home gardens: neglected hotspots of agro-biodiversity and cultural diversity. Biodiversity and Conservation, vol. 19, no. 13, p. 36353654. http://dx.doi.org/10.1007/s10531-010-9919-5

GLIESSMAN, SR., 2005. Agroecologia: processos ecológicos em agricultura sustentável. 3. ed. Porto Alegre: Editora da UFRGS. 592 p.

GODOY, CMT., PÉREZ, FIC., WIZNIEWSKY, JG., GUEDES, AC. and MORAES, CS., 2010. Juventude rural, envelhecimento e o papel da aposentadoria no meio rural: A realidade do município de Santa Rosa/RS. In Anais do XLVIII Congresso da Sociedade Brasileira de Economia, Administração e Sociologia Rural, 2010. Campo Grande: SOBER. p. 1-18.

Instituto Brasileiro de Geografia e Estatística - IBGE, 2012. Available from: $<$ http://www.ibge.gov.br $>$. Access in: 23 june 2012.

IJOYAH, MO., 2011. Yield effects of intercropping white guinea yam (Dioscoreae rotundata P.) minisetts and maize (Zea mays L.) 
in the southern Guinea savanna of Nigeria. African Journal of Agricultural Research, vol. 6, no. 23, p. 5227-5231.

JARVIS, DI., MYER, L., KLEMICK, H., GUARINO, L., SMALE, M., BROWN, AHD., SADIKI, M., STHAPIT, B. and HODGKIN, T., 2000. A training guide for in situ conservation on farm. version 1. Rome: IPGRI. $190 \mathrm{p}$.

JULIATTI, JC., SARAIVA, JST., COSTA, EB. and CARMO, CCS., 2002. Análise conjuntural sobre as culturas do taro e do inhame no estado do Espirito Santo. In: CARMO, CAS. (Ed.). Inhame e taro: sistemas de produção familiar. Vitória: Incaper. p. 51-60.

KÖEPPEN, W., 1948. Climatologia: con un estudio de los climas de la tierra. México: Fondo de Cultura Econômica. 479 p.

LEBOT, V., 2009. Tropical root and tuber crops: cassava, sweet potato, yams and aroids. Crop production science in horticulture series: 17. Wallingford: CABI. $432 \mathrm{p}$.

MORELLATO, LPC., TALORA, DC., TAKAHASI, A., BENCKE, CC., ROMERA, EC. and ZIPPARRO, VB., 2000. Phenology of Atlantic Rain Forest trees: a comparative study. Biotropica, vol. 32, no. 4, p. 811-823. http://dx.doi.org/10.1646/00063606(2000)032[0811:POARFT]2.0.CO;2

MILLER, RP. and NAIR, PKR., 2006. Indigenous agroforestry systems in Amazonia: from prehistory to today. Agroforestry Systems, vol. 66, no. 2, p. 151-164. http://dx.doi.org/10.1007/ s10457-005-6074-1

MONTEIRO, DA. and PERESSIN, VA., 2002. Cultura do inhame. In: CEREDA, MP. (Coord.). Agricultura: tuberosas amiláceas Latino Americanas. São Paulo: Fundação Cargill. p. 511-518.

ODEBUNMI, EO., OLUWANIYI, OO., SANDA, AM. and KOLADE, BO., 2007. Nutritional compositions of selected tubers and root crops used in Nigerian food preparations. International Journal of Chemistry, vol. 17, no. 1, p. 37-43.

OKOLI, OO. and ONWUEME, IC., 1986. Yam and the African food crisis. In Proceedings of the III Symposium of the International Society for Tropical Root Crops. Owerri: ISTRB-AC. p. 50-54.

OTANI, MN., SOUZA, MCM., MOREIRA, SR., CASTRO, CE., MARCHIORI, A., OLIVEIRA, MDM. and TURCO, PHN., 2011. Caracterização sociocultural dos agricultores familiares de Ubatuba, Estado de São Paulo. Informações Econômicas, vol. 41, no. 4, p. 17-28.

PEDRALLI, G., 2002. Distribuição geográfica e taxonomia das famílias Araceae e Dioscoreaceae no Brasil. In CARMO, CAS. (Ed.). Inhame e taro: sistemas de produção familiar. Vitória: Incaper. p. 15-26.

PEDRALLI, G., CARMO, CA., CEREDA, M. and PUIATTI, M., 2002. Uso de nomes populares para as espécies de Araceae e Dioscoreaceae no Brasil. Horticultura Brasileira, vol. 20, p. 530-532. http://dx.doi.org/10.1590/S0102-05362002000400002

PEIXOTO NETO, PAS., LOPES FILHO, J., CAETANO, LC., ALENCAR, LMC. and LEMOS, EEB., 2000. Inhame: o Nordeste fértil. Maceió: EDUFAL. 88 p.

SANTOS, ES., 1996. Aspectos básicos da cultura do inhame (Dioscorea spp.). João Pessoa: EMEPA, SEBRAE. 158p.

SANTOS, ES. and MACÊDO, LS., 2002. Tendências e perspectivas da cultura do inhame (Dioscorea sp.) no Nordeste do Brasil. In Anais do II Simpósio Nacional Sobre as Culturas de Inhame e Taro, 2002. João Pessoa: EMEPA. p. 19-32.
SCHNEIDER, S., 2003. Teoria social, agricultura familiar e pluriatividade. Revista Brasileira de Ciências Sociais, vol. 18, no. 51, p. 99-122. http://dx.doi.org/10.1590/S0102-69092003000100008

SIQUEIRA, MVBM., 2011. Yam: a neglected and underutilized crop in Brazil. Horticultura Brasileira, vol. 29, no. 1, p. 16-20.

SIQUEIRA, MVBM. and VEASEY, EA., 2009. Raíces y tubérculos tropicales olvidados o subutilizados en Brasil. Revista Colombiana de Ciências Hortícolas, vol. 3, no. 1, p. 110-125.

SIQUEIRA, MVBM., PINHEIRO, TT., BORGES A., VALLE, TL., ZATARIM, M. and VEASEY, EA., 2010. Microsatellites polymorphism in cassava landraces from the Cerrado biome, Mato Grosso do Sul, Brazil. Biochemical Genetics, vol. 48, no. 9-10, p. 879-895. PMid:20668929. http://dx.doi.org/10.1007/ s10528-010-9369-5

VAN VLIET, N., MERTZ, O., HEINIMANN, A., LANGANKE, T., PASCUAL, U., SCHMOOK, B., ADAMS, C., SCHMIDTVOGT, D., MESSERLI, P., LEISZ, S., CASTELLA, J., JORGENSEN, L., BIRCH-THOMSEN, T., HETT, C., BECH-BRUUN, T., ICKOWITZ, A., VU, K., YASUYUKU, K., FOX, J., PADOCH, C., DRESSLER, W., and ZIEGLER, A., 2012. Trends, drivers and impacts of changes in swidden cultivation in tropical forest-agriculture frontiers: a global assessment. Global Environmental Change, vol. 22, p. 418-429. http://dx.doi.org/10.1016/j.gloenvcha.2011.10.009

VEASEY, EA., BRESSAN, EA., SIQUEIRA, MVBM., BORGES, A., QUEIROZ-SILVA, JR., PEREIRA, KJC., RECCHIA, GH. and MING, LC., 2012. Genetic characterization of cassava (Manihot esculenta Crantz) and yam (Dioscorea trifida L.) landraces in swidden agriculture systems in Brazil. In GEPTS, P., FAMULA, T., BETTINGER, R., QUALSET, C., MCGUIRE, P., BRUSH, S. and DAMANIA, A. (Eds.). Biodiversity in agriculture: domestication, evolution and sustainability. Cambridge: Cambridge University Press. p. 344-360.

VEASEY, EA., SIQUEIRA, MVBM., GOMES, LR., NASCIMENTO, WF., FERREIRA, AB., SILVA, DM., SILVA, EF., MING, LC., PERONI, N. and SANTOS, AH., 2010. Ocorrência e diversidade de espécies cultivadas do gênero Dioscorea em diversos agroecossistemas brasileiros. In KFFURI, CW., AMOROZO, MC. and MING, LC. (Eds.). Agrobiodiversidade no Brasil: experiências e caminhos da pesquisa. Recife: NUPEEA. vol. 1, p. 45-74.

WANDERLEY, M.N.B., 2000. The importance of family farming and the demands of rurality in Brazil. Desenvolvimento e Meio Ambiente, vol. 2, p. 29-37.

WINKLERPRINS, AMGA., 2002. House-lot gardens in Santarém, Pará, Brazil: linking rural with urban. Urban Ecosystems, vol. 6, no. 1-2, p. 43-65.

WOORTMANN, K., 1990. Migração, família e campesinato. Revista Brasileira de Estudos de População, vol. 7, no. 1, p. 35-53. PMid:12284366.

ZÁRATE, NAH., VIEIRA, MC. and MINUZZI, A., 2002. Brotação de seis tipos de mudas dos clones de inhame roxo e mimoso. Ciência e Agrotecnologia, vol. 26, no. 4, p. 699-704. 